\title{
Similarity of vasopressin receptors in seminal vesicles and renal medulla of pigs
}

\author{
M. Maggi, M. De Rossi $\uparrow$ F. Amenta $\uparrow$, A. D. Genazzani, D. Rodbard* and \\ M. Serio
}

\section{Endocrinology Unit, University of Florence, 50134 Florence, Italy; $\dagger$ Department of Neurological}

Science, 'La Sapienza' University, Rome, Italy; and *Laboratory of Theoretical and Physical Biology, National Institute of Child Health and Human Development, National Institutes of Health, Bethesda MD, 20892, U.S.A.

\begin{abstract}
Summary. To test the hypothesis that the vasopressin receptors found in seminal vesicles are similar to those present in the renal tubules competition experiments were performed with vasopressin and several analogues with different specificities for the V1 and V2 subtypes of vasopressin receptor. Autoradiographic studies were carried out on sections from seminal vesicles and kidney to identify the cellular target of vasopressin. Vasopressin receptors in renal medulla and seminal vesicles of pigs shared the same rank order of potency for vasopressin and its analogues and were localized in the epithelium of the seminal vesicles and in collecting tubules of renal medulla. These results strongly suggest that the vasopressin receptors present in kidney and seminal vesicles belong to the same subtype, $\mathrm{V} 2$, of vasopressin receptor.
\end{abstract}

Keywords: arginine vasopressin; seminal vesicles; kidney; receptors; pigs

\section{Introduction}

Vasopressin receptors have been classified into two different subtypes, the calcium-dependent V1 receptors, present in blood vessels (Penit et al., 1983) and liver (Cantau et al., 1980), and the cyclic AMP-dependent V2 receptors, present in the medullary portion of the kidney (Bockaert et al., 1973).

Arginine vasopressin (AVP) receptors have been identified in brain (Pearlmutter et al., 1983), in the interstitial cells of the testis (Meidan \& Hsueh, 1985), in several portions of the male genital tract (Maggi et al., 1987) and in urinary bladder and spleen (Thibonnier et al., 1987). All these sites seem to have the V1 subtype of AVP receptors.

We have identified and characterized a high concentration of AVP binding sites in the seminal vesicles of pigs (Maggi et al., 1986). These receptors are linked to adenylate cyclase and display pharmacological characteristics different from those previously described for V1 AVP sites. These properties suggested to us that the AVP receptors in seminal vesicles were similar to the V2 receptors. However, the selective V2 agonist [1-deamino, 4-valine]D-Arg ${ }^{8}$-vasopressin (dVDAVP) exibited low affinity for this site and the V1 antagonist [1-deaminopenicillamine, 2-(0methyl)tyrosine] $\mathrm{Arg}^{8}$-vasopressin (dPenTyrMeAVP) competed in nanomolar concentrations for $\left[{ }^{3} \mathrm{H}\right] \mathrm{AVP}$ binding. Initially, we interpreted these results as indicating that vasopressin receptors in seminal vesicles were distinct from those of the V1 and V2 subtypes, and possibly related to those of the anterior pituitary (Antoni, 1984). However, the pig kidney differs from other species in terms of its pharmacological profile of affinities for several vasopressin analogues (Butlen et al., 1978; S. Jard, personal communication). We have therefore reinvestigated the AVP receptors in seminal vesicle and kidney tissues of pigs under the same experimental conditions. Autoradiography was used to examine the target cells for vasopressin in the seminal vesicles and kidney. 


\section{Materials and Methods}

Binding studies. $\left[{ }^{3} \mathrm{H}\right] \mathrm{AVP}$ (sp. act. $70 \mathrm{Ci} / \mathrm{mmol}$ ) was purchased from New England Nuclear (Boston, MA, U.S.A.). To minimize degradation the tritiated ligand was placed in plastic tubes, sealed under nitrogen, and frozen at $-80^{\circ} \mathrm{C}$. AVP, dPenTyrMeAVP and [1-deamino]D-Arg ${ }^{8}$-vasopressin (dDAVP) were from Sigma (St Louis, MO, U.S.A.). [1-( $\beta$ Mercapto- $\beta$. $\beta$-cyclopentamethylene propionic acid), 2-(0-methyl)tyrosine]Arg ${ }^{8}$-vasopressin $\left(\mathrm{d}\left(\mathrm{CH}_{2}\right)_{5} \mathrm{TyrMeAVP}\right.$ was from Peninsula Laboratories (San Carlos, CA, U.S.A.). [Thr ${ }^{4}$, Gly $\left.^{7}\right]$ Oxytocin and $\left[1-\right.$ deamino,4-valine]D-Arg ${ }^{8}-$ vasopressin (dVDAVP) were synthesized and generously provided by Dr M. Manning (Medical College of Ohio, Toledo, OH, U.S.A.).

Domestic pigs, 1 month of age, were obtained from Cimex (Florence, Italy). Membrane fractions were prepared from seminal vesicles and from medullopapillary portions of kidneys according to the procedures previously described (Maggi et al., 1986, 1987). Briefly, tissues were homogenized in Buffer 1 (10 mM-Tris $-\mathrm{HCl}, \mathrm{pH} \mathrm{7.4/1 \cdot 5} \mathrm{mM-}$ EDTA $/ 0.5 \mathrm{~mm}$-dithiothreitol $/ 1 \mathrm{~mm}$-benzamidine $/ 0.01 \%$ bacitracin $/ 0.002 \%$ soybean trypsin inhibitor) and crude membrane fractions were prepared by differential centrifugation between $1000 \mathrm{~g}(10 \mathrm{~min})$ and $160000 \mathrm{~g}(30 \mathrm{~min})$. The pellets were washed once in Buffer $2\left(50 \mathrm{~mm}\right.$-Tris maleate, $\mathrm{pH} 7 \cdot 6 / 10 \mathrm{~mm}-\mathrm{MgSO}_{4} / 1 \mathrm{~mm}$-benzamidine $/ 0 \cdot 01 \%$ bacitracin $/ 0.002 \%$ soybean trypsin inhibitor). The membrane preparations were divided into small aliquants at a protein concentration of $2-4 \mathrm{mg} / \mathrm{ml}$, frozen in solid $\mathrm{CO}_{2}$ and stored at $-80^{\circ} \mathrm{C}$ until assayed.

For receptor binding studies aliquants of membrane $(0.2 \mathrm{mg} / \mathrm{ml})$ were incubated with $\left[{ }^{3} \mathrm{H}\right] \mathrm{AVP}(0.075-0.6 \mathrm{nM})$ with or without increasing concentrations of unlabelled peptides. According to our previous findings, AVP is not selective for AVP receptors (Maggi et al., 1986, 1987). AVP has a $K_{\mathrm{d}}$ in the nanomolar range for the AVP and oxytocin receptors. We therefore used $50 \mathrm{~nm}$ of the selective oxytocin agonist $\left[\mathrm{Thr}^{4}, \mathrm{Gly}^{7}\right.$ ]oxytocin to block the oxytocin sites. [Thr $\left.{ }^{4}, \mathrm{Gly}^{7}\right]$ oxytocin at this concentration completely displaced $\left[{ }^{3} \mathrm{H}\right]$ oxytocin from seminal vesicles membranes, but failed to affect $\left[{ }^{3} \mathrm{H}\right] \mathrm{AVP}$ binding (Maggi et al., 1986). Binding reactions were carried out in Buffer 2 containing $0.1 \%$ bovine serum albumin (BSA), at $22^{\circ} \mathrm{C}$ for $60 \mathrm{~min}$. Bound radioactivity was separated by rapid filtration through a Whatman GF/B filter using the M-48R Cell-Harvester (Brandel, Gaithersburg, MD, U.S.A.). Radioactivity retained on the filters was measured by liquid scintillation spectrometry $12 \mathrm{~h}$ after the addition of $10 \mathrm{ml}$ Atomlight (Beckman). Protein content was measured using the Pierce protein assay reagent (Pierce Chemical Co., Rockford, IL, U.S.A.), based on the method of Bradford (1976). The results were analysed using the computer programs ALLFIT (De Lean et al., 1978) and LIGAND (Munson \& Rodbard, 1980).

Autoradiography. The autoradiographic study was carried out according to the protocol proposed by Young \& Kuhar (1979). Tissue specimens were quickly frozen in isopentane cooled with liquid nitrogen. Serial sections (6$8 \mu \mathrm{m}$ thick) of seminal vesicles and kidney cortex and medulla were obtained using a microtome cryostat and mounted on gelatin-coated microscope slides. The slides were air-dried at room temperature for 30 min and then preincubated at $4^{\circ} \mathrm{C}$ for $30 \mathrm{~min}$ in Buffer 1 containing $0.1 \%$ BSA. The slides were then washed twice at $4^{\circ} \mathrm{C}$ for $5 \mathrm{~min}$ in Buffer 2 containing $0.1 \% \mathrm{BSA}$ and then incubated in the same buffer at $22^{\circ} \mathrm{C}$ for 60 min in the presence of $1 \mathrm{nM}-\left[{ }^{3} \mathrm{H}\right] \mathrm{AVP}$ and $50 \mathrm{nM}-\left[\mathrm{Thr}^{4}, \mathrm{Gly}^{7}\right]$ oxytocin. Control sections were incubated in the same way but in the presence of $1 \mu \mathrm{M}-\mathrm{AVP}$, to estimate the non-specific binding. At the end of the incubation, the slides were washed twice in ice cold $50-\mathrm{mm}$-Tris- $\mathrm{HCl} \mathrm{pH} 7.4$ for $5 \mathrm{~min}$, air dried and fixed by exposure to formaldehyde vapour at $80^{\circ} \mathrm{C}$ for $60 \mathrm{~min}$.

Coverslips coated with nuclear emulsion Ilford L4 (diluted 1:1, v/v, with distilled water) were applied to the sections which were kept in darkness at $4^{\circ} \mathrm{C}$ for 48 weeks. The slides were then developed in Kodak D-19, fixed, stained with toluidine blue or haematoxylin and eosin, and observed with dark- and bright-field microscopy. The sections stained with toluidine blue or haematoxylin and eosin were used for anatomical correlation. For further details on the autoradiographic procedures see Amenta (1986).

\section{Results}

\section{Binding studies}

Figure 1(a) shows a family of competition curves obtained in seminal vesicle membranes. AVP and the V1 antagonist dPenTyrMeAVP competed with high affinity for $\left[{ }^{3} \mathrm{H}\right] \mathrm{AVP}$ binding. The V2 agonists dVDAVP and dDAVP and the other V1 antagonist $\mathrm{d}\left(\mathrm{CH}_{2}\right)_{5}$ TyrMeAVP tested showed lower potency. These results are in excellent agreement with our previous findings (Maggi et al., 1986). Similar binding specificity was obtained in medullopapillary membranes (Fig. 1b).

Table 1 indicates the concentrations of receptors (binding capacity) and the affinity constant $\left(K_{d}\right)$ in seminal vesicles and kidney medulla. These values were obtained by analysis with the program LIGAND (Munson \& Rodbard, 1980). The affinities of the various peptides tested were virtually identical in both tissues. 


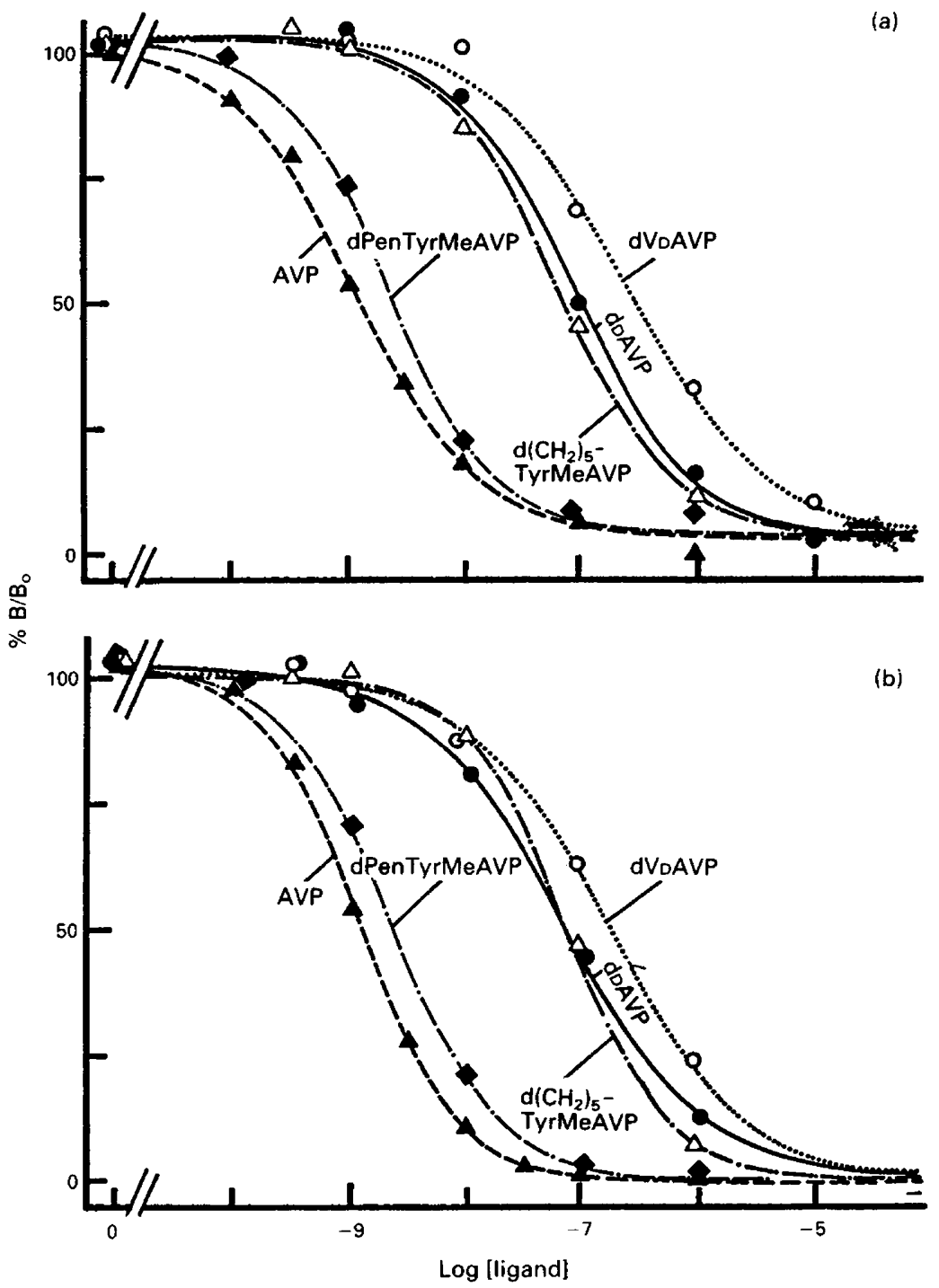

Fig. 1. Displacement of specific $\left[{ }^{3} \mathrm{H}\right]$ AVP binding in (a) seminal vesicles and (b) the medullopapillary portion of the kidney of pigs by AVP and several synthetic analogues. Membranes $(0.2 \mathrm{mg} / \mathrm{ml})$ were incubated for $60 \mathrm{~min}$ at $22^{\circ} \mathrm{C}$ with $0.6 \mathrm{nM}-\left[{ }^{3} \mathrm{H}\right] \mathrm{AVP}$ in the presence or absence of increasing concentrations of AVP $(\Delta)$, dPenTyrMeAVP $(\diamond), \mathrm{d}\left(\mathrm{CH}_{2}\right)_{5} \operatorname{TyrMeAVP}(\triangle)$, dDAVP ( $)$ or dVDAVP $(O)$. A blocking concentration $(50 \mathrm{nM})$ of the selective oxytocin agonist $\left[\mathrm{Thr}^{4}, \mathrm{Gly}^{7}\right]$ oxytocin was present to mask the cross-reactivity of AVP to the oxytocin receptors.

\section{Autoradiography}

Figure 2 shows the main findings concerning the autoradiographic localization of $\left[{ }^{3} \mathrm{H}\right] \mathrm{AVP}$ within seminal vesicles and renal medulla. In seminal vesicles specific $\left[{ }^{3} \mathrm{H}\right] \mathrm{AVP}$ receptors were located almost exclusively in the epithelium (Fig. $2 \mathrm{a}-\mathrm{e}$ ). In the renal sections, $\left[{ }^{3} \mathrm{H}\right] \mathrm{AVP}$ was bound to the epithelial cells of collecting tubules of the outer and inner medulla (Fig. $2 \mathrm{f}$ and $\mathrm{g}$ ). In contrast, the renal cortex developed only non-specific binding (data not shown). 
Table 1. Concentrations of receptors and affinities expressed as $K_{\mathrm{d}}$ for AVP, d $\left(\mathrm{CH}_{2}\right)_{5}$ TyrMeAVP, dPenTyrMeAVP, dVDAVP and dDAVP in membranes from seminal vesicles and renal medulla of pigs

\begin{tabular}{lcc}
\hline & $\begin{array}{c}\text { Seminal } \\
\text { vesicles }\end{array}$ & $\begin{array}{c}\text { Renal } \\
\text { medulla }\end{array}$ \\
\hline $\begin{array}{l}\text { Binding capacity } \\
\text { (fmol/mg protein) }\end{array}$ & $246 \pm 26$ & $498 \pm 29$ \\
$K_{\mathrm{d}}(\mathrm{nM})$ & & \\
AVP & $0 \cdot 4 \pm 0 \cdot 07$ & $0 \cdot 3 \pm 0.03$ \\
d(CH $)_{5}$ TyrMeAVP & $28 \cdot 3 \pm 7 \cdot 3$ & $25 \cdot 0 \pm 3 \cdot 5$ \\
dPenTyrMeAVP & $0 \cdot 8 \pm 0 \cdot 2$ & $0 \cdot 7 \pm 0 \cdot 1$ \\
dVDAVP & $141.2 \pm 36.7$ & $89.7 \pm 11 \cdot 6$ \\
dDAVP & $42.5 \pm 10 \cdot 6$ & $38 \cdot 8 \pm 6 \cdot 2$ \\
\hline
\end{tabular}

Values are mean \pm s.e.m. of 3 experiments on pooled membranes derived from 4 prepubertal pigs.

\section{Discussion}

Our results support the presence of V2 (renal) vasopressin receptors in seminal vesicles of pigs. While VI AVP receptors have been localized in several peripheral tissues, this study, together with our previous results (Maggi et al., 1986), clearly indicates the presence of the V2 subtype of AVP receptors outside the kidney.

Binding competition studies performed in membranes prepared from pig seminal vesicles and kidney strongly suggest that the vasopressin receptors present in these tissues belong to the same subtype of vasopressin receptors. The finding that the two selective V2 (renal) vasopressin analogues tested in competition experiments exhibited low affinity for $\left[{ }^{3} \mathrm{H}\right] \mathrm{AVP}$ binding in seminal vesicles and renal medulla of pigs is not surprising. Butlen et al. (1978) reported a different structural requirement for binding to pig or rat renal receptors. dVDAVP and dDAVP were potent ligands for the V2 receptors present in the rat kidney but had relatively low potency in the pig kidney in terms of binding or stimulation of adenylate cyclase.

The concentrations of AVP sites in seminal vesicles reported in the present study are 10-fold lower than those previously observed by us (Maggi et al., 1986). However, there are differences in the age ( 1 month versus 3 months old) and the breed (domestic versus miniature pigs) of the animals used in these two studies. We are planning to perform further studies to clarify whether the density of AVP receptors in seminal vesicles is affected by age, breed or hormonal milieu.

Fig. 2. Autoradiographic demonstration of $\left[{ }^{3} \mathrm{H}\right] \mathrm{AVP}$ binding sites within seminal vesicles and renal medulla of pigs. (a) Section of pig seminal vesicle stained with haematoxylin and eosin. Seminal vesicles have three tunics: an external areolar (a), a middle muscular (m) and an internal mucosa (arrow). $\times 40$. (b) Higher magnification of (a). The mucous tunic surrounding the lumen $(\mathrm{L})$, consists primarily of columnar epithelium cells (e). $\times 125$. (c) Autoradiography of pig seminal vesicle incubated with $1 \mathrm{nM}-\left[{ }^{3} \mathrm{H}\right] \mathrm{AVP}$ and $50 \mathrm{nM}-\left[\mathrm{Thr}^{4}\right.$, Gly $\left.{ }^{7}\right]$ oxytocin in the presence of $1 \mu \mathrm{M}$-AVP showing a complete suppression of binding of labelled ligand. Dark field, $\times 125$. (d) and (e) Autoradiography of sections of seminal vesicles after incubation with $1 \mathrm{nM}-\left[{ }^{3} \mathrm{H}\right] \mathrm{AVP}$ and $50 \mathrm{nM}-\left[\mathrm{Thr}^{4}, \mathrm{Gly}^{7}\right]$ oxytocin to block oxytocin receptors. Silver grains are located only within the epithelial cells (e) of the mucosa. $\mathrm{L}=$ lumen. Dark field: $d, \times 125$; e, $\times 160$. (f) Section of renal medulla stained with haematoxylin and eosin. Arrows indicate collecting tubules. $\times 80$. (g) Section of pig renal medulla incubated with $1 \mathrm{nM}-\left[{ }^{3} \mathrm{H}\right] \mathrm{AVP}$ and $50 \mathrm{nM}-\left[\mathrm{Thr}^{4}, \mathrm{Gly}^{7}\right]$ oxytocin and processed for autoradiography. Specific silver grains are located at the level of the epithelial cells of the collecting tubules (t). Dark field, $\times 80$. 


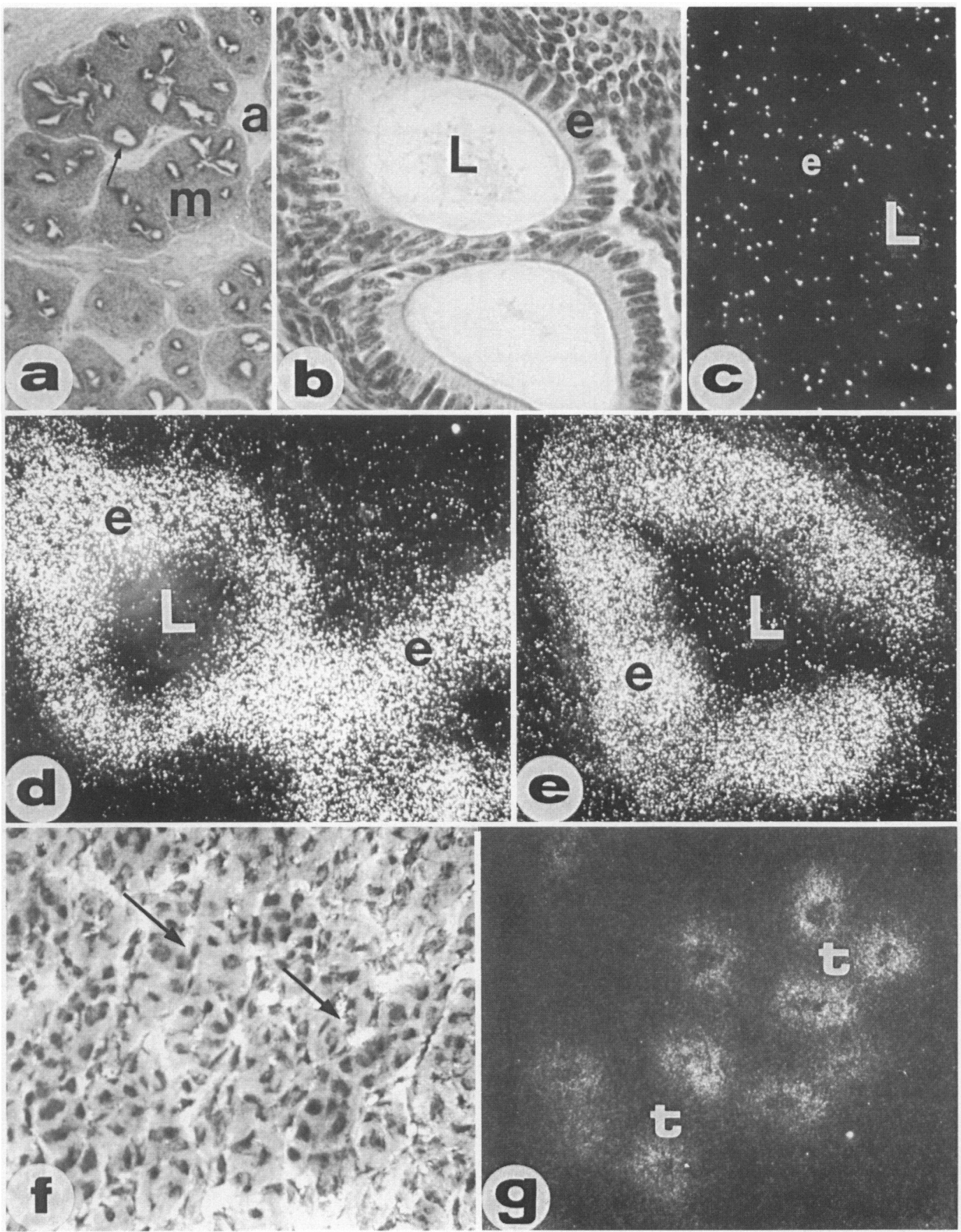


The autoradiographic analysis of the anatomical localization of vasopressin receptors shows that in the kidney they are located, as expected, in the epithelial cells lining the medullary tubules, but not in the cortex (see Dorsa et al., 1983). In the seminal vesicles AVP receptors were found in the epithelial cells facing the lumen of the glands. These findings, together with evidence that AVP receptors are coupled to adenylate cyclase in the kidney (Butlen et al., 1978) and seminal vesicles (Maggi et al., 1986), further indicate the similarity if not identity of AVP receptors in these two tissues. We therefore revise our previous interpretation that the seminal vesicle vasopressin receptors is of a subtype different from V1 or V2 receptors (Maggi et al., 1986).

Renal vasopressin receptors regulate tubular fluid osmolarity, using cAMP as a second messenger. In contrast, the role of AVP receptors in the epithelial cells of the seminal vesicles is still obscure. Levine et al. (1975) showed that there is a cAMP-dependent active secretion $\mathrm{Cl}^{-}$in guinea-pig seminal vesicles and suggested that this active secretion may be a driving force for the initial secretion of electrolyte. Following this secretory phase, water and electrolytes are reabsorbed, resulting in an increased concentration of organic components. It is tempting to speculate that AVP affects one or several of the various steps involved in the regulation of seminal fluid osmolarity and perhaps other secretory activities of the epithelial cells of these glands. A large volume of fluid is produced by pig seminal vesicles, and the final volume of the ejaculate $(200-500 \mathrm{ml})$ is two orders of magnitude higher than that of many other mammals. The presence of vasopressin receptors in the seminal vesicles of other animal species is under investigation.

We thank Dr Serge Jard (Centre C.N.R.S.-I.N.S.E.R.M. de Pharmacologie-Endocrinologie, Montpellier, France), for comments on the pharmacological profiles of various AVP analogues and Dr Maurice Manning (Medical College of Ohio, Toledo, OH, U.S.A.) for generous provision of several synthetic analogues.

This paper was financially supported by a grant from the University of Florence and partially by Fidia Pharmaceuticals, Abano Terme, Padua, Italy.

\section{References}

Amenta, F. (1986) Autoradiographic localization of GABA receptor sites in peripheral tissues. In $G A B A$ ergic Mechanisms in the Mammalian Periphery, pp. 99-115. Eds S. L. Erdo \& N. G. Bowery. Raven Press, New York.

Antoni, F.A. (1984) Novel ligand specificity of pituitary vasopressin receptors in the rat. Neuroendocrinology 39, $186-188$.

Bockaert, J., Roy, C., Rajerison, R. \& Jard, S. (1973) Specific binding of $\left[{ }^{3} \mathrm{H}\right]$ lysine-vasopressin to pig kidney plasma membranes. Relationship of receptors occupancy to adenylate cyclase activation. J. biol. Chem. 248, 5922-5931.

Bradford, M.M. (1976) A rapid and sensitive method for quantitation of microgram quantities of protein, utilizing the principle of protein-dye binding. Analyt. Biochem. 72, 248-254.

Butlen, D., Guillon, G., Rajerison, R.M., Jard, S., Sawyer, W.H. \& Manning, M. (1978) Structural requirements for activation of vasopressin-sensitive adenylate cyclase, hormone binding, and antidiuretic actions: effects of highly potent analogues and competitive inhibitors. Molec. Pharm. 14, 1006-1017.

Cantau, B., Keppens, S., De Wulf, H. \& Jard, S. (1980) Vasopressin binding to isolated rat hepatocytes and liver membranes: regulation by GTP and relation to glycogen phosphorylase activation. J. Receptor Res. 1, 137-168.

De Lean, A., Munson, P.J. \& Rodbard, D. (1978) Simultaneous analysis of families of sigmoidal curves: application to bioassay, radioligand assay, and physiological dose-response curves. Am. J. Physiol. 235, E97-E102.

Dorsa, D.M., Majumdar, L.A., Petracca, F.M., Baskin, D.G. \& Cornett, L.E. (1983) Characterization and localization of $\left[{ }^{3} \mathrm{H}\right]$ Arginine 8 -vasopressin binding to rat kidney and brain tissue. Peptides 4, 699-706.

Levine, N., Rinaldo, J.E. \& Schultz, S.G. (1975) Active chloride secretion by "in vitro" guinea-pig seminal vesicles and its possible relation to vesicular function “in vivo". J. Physiol., Lond. 246, 197-211.

Maggi, M., Kassis, S., Malozowski, S., Guardabasso, G. \& Rodbard, D. (1986) Identification and characterization of a vasopressin isoreceptor in porcine seminal vesicles. Proc. natn. Acad. Sci. U.S.A. 83, 8824-8828.

Maggi, M., Malozowsky, S., Kassis, S., Guardabasso, G. \& Rodbard, D. (1987) Identification and characterization of two classes of oxytocin and vasopressin (V1) receptors in porcine tunica albuginea, epididymis and vas deferens. Endocrinology 120, 986-994. 
Meidan, R. \& Hsueh, A.J.W. (1985) Identification and characterization of arginine vasopressin receptors in the rat testis. Endocrinology 116, 416-423.

Munson, P.J. \& Rodbard, D. (1980) LIGAND: a versatile computerized approach for characterization of ligand-binding system. Analyt. Biochem. 107, 220-239.

Pearlmutter, A.F., Costantini, M.G. \& Loeser, B. (1983) Characterization of ${ }^{3} \mathrm{H}$-AVP binding sites in particulate preparations of rat brain. Peptides 4, 335-341.
Penit, J., Faure, M. \& Jard, S. (1983) Vasopressin and angiotensin II receptors in rat aorta muscle cells in culture. Am. J. Physiol. 244, E72-E82.

Thibonnier, M., Snajdar, R.M. \& Rapp, J.P. (1987) Characterization of vasopressin receptors of rat urinary bladder and spleen. Am. J. Physiol. 251, H115-H120.

Young, W.S. \& Kuhar, M.J. (1979) A new method for receptor autoradiography: ${ }^{3} \mathrm{H}$-opioid receptors in rat brain. Brain Res. 179, 255-270.

Received 2 December 1987 